\title{
Temporal and spatial variations of vegetation in a riparian zone of South Korea
}

\author{
Hyekyung Park' and Jae Geun Kim ${ }^{1,2^{*}}$
}

\begin{abstract}
Understanding vegetation structure and the relationship with environmental factors has been crucial for restoration and conservation of riparian zones. In this study, we conducted field survey in a riparian zone of Namhan River in South Korea both before and after flooding in order to understand temporal and spatial variations of riparian vegetation. There were significant temporal and spatial variations in species composition, and distribution patterns of vegetation were different along a gradient of elevation above the water level. At low elevation, Zizania latifolia was dominant throughout the field survey periods, and Bidens frondosa began to grow late and dominated both in post-flooding 1 and 2. Prior to flooding, Scirpus radicans and Polygonum thunbergii were widely distributed at middle elevation, while Artemisia vulgaris, Phragmites australis, and Miscanthus sacchariflorus were dominant at high elevation. After flooding, P. thunbergii was dominant at middle elevation with most other species decreasing, and more invasive or pioneer plants, including Artemisia princeps, H. scandens, and Sicyos angulatus, were observed at high elevation. Species composition and distribution patterns were homogeneous at low elevation, whereas dynamic variations of vegetation were observed both temporally and spatially at higher elevations. Elevation and distance from the water front were the most principal factors governing vegetation structure. Furthermore, soil physicochemical properties were also found to determine species composition and distribution patterns. These results indicate that vegetation structure in the riparian zones is formed by the combined effects of hydrological regime and soil physicochemical properties, inherent characteristics of species, and interspecific competition. Understanding of temporal and spatial variations of riparian vegetation may provide useful insights into ecological restoration and conservation of the vegetation within the riparian zones.
\end{abstract}

Keywords: Distribution pattern, Elevation, Flooding, Hydrological Gradient, Species composition

\section{Background}

Riparian zones, occurring as ecotones between terrestrial and aquatic ecosystems, are featured by unique environmental gradients. Vegetation structure of a riparian zone is a reflection of such gradients (Naiman et al. 2005). By serving as biological buffers, riparian vegetation is essential for providing habitats, reducing erosion, maintaining stream channel morphology, and improving water

\footnotetext{
* Correspondence: jaegkim@snu.ac.kr

'Department of Biology Education, Seoul National University, Seoul 08826, Republic of Korea

${ }^{2}$ Center for Education Research, Seoul National University, Seoul 08826, Republic of Korea
}

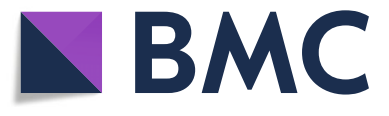

() The Author(s). 2020 Open Access This article is licensed under a Creative Commons Attribution 4.0 International License, which permits use, sharing, adaptation, distribution and reproduction in any medium or format, as long as you give appropriate credit to the original author(s) and the source, provide a link to the Creative Commons licence, and indicate if changes were made. The images or other third party material in this article are included in the article's Creative Commons licence, unless indicated otherwise in a credit line to the material. If material is not included in the article's Creative Commons licence and your intended use is not permitted by statutory regulation or exceeds the permitted use, you will need to obtain permission directly from the copyright holder. To view a copy of this licence, visit http://creativecommons.org/licenses/by/4.0/

quality (Knight and Bottorff 1984, Darby 1999, Tabacchi et al. 2000, Dosskey et al. 2010). It has been crucial to understand distinctive characteristics of vegetation structure and the relationship with environmental factors for restoration and conservation of riparian zones (Fail et al. 1987, Pennington et al. 2008).

Hydrological gradient is inferred as a primary factor governing riparian vegetation (Auble et al. 2005, Chen et al. 2015). In riparian zones, flooding is the most important disturbance controlling the establishment and development of vegetation (Ferreira and Stohlgren 1999, Casanova and Brock 2000). Flood pulses vary in their 
seasonal timing, frequency, duration, and magnitude. Elevation above the water level and distance from the water front reflect such characteristics of flooding thereby creating temporal and spatial gradients of hydrological regime. Plants inhabiting riparian zones either have a remarkable tolerance of flooding via physiological or morphological traits (Vandersande et al. 2001, Parolin 2002, Xiaoling et al. 2011) or avoid the effects of flooding through timing of life cycle (Blom and Voesenek 1996). Species composition and distribution patterns in riparian zones therefore reflect hydrological regime and species differences in tolerance to drought or floods (Shafroth et al. 2002, Auble et al. 2005, Capon 2005).

Besides, the gradients of soil environments are also important in determining the vegetation structure (Nilsson et al. 1989). Flooding affects soil environments including organic matter content, soil particle distribution, and nutrient availability through sedimentation and change of oxygen availability (Baldwin and Mitchell 2000, Steiger et al. 2005, Polvi et al. 2011). Hefting et al. (2004) reported that in a riparian zone, groundwater table fluctuation was a key factor of the $\mathrm{N}$ cycle which regulates plant productivity. Jolley et al. (2010) found out changes in plant community composition across a gradient of increasing sedimentation rates in riparian forests. That is, changes in hydrological regime alter the soil environments, and thus may lead to shifts in vegetation structure. Furthermore, flooding is expected to change the main soil physicochemical properties affecting vegetation structure.

In this study, we conducted field survey in a riparian zone of Namhan River in South Korea both before and after flooding in order to understand temporal and spatial variations of riparian vegetation. The specific objectives of our study were (1) to determine temporal and spatial variations of species composition and distribution patterns of vegetation along the elevation above the water level and (2) to elucidate the major environmental factors determining vegetation structure.

\section{Methods}

\section{Study site and field survey}

Field survey was conducted in a riparian zone of Namhan River in Yeoju City, Gyeonggi Province, South Korea (37 $26^{\prime} \mathrm{N}, 127^{\circ} 30^{\prime} \mathrm{E}$ ) (Additional file 1: Figure S1). The site was upstream of Ipo Weir, and the river width was about $300 \mathrm{~m}$. The site received $936 \mathrm{~mm}$ of rainfall between January and October 2019, and the temperature ranged from - 6.4 to $30.5{ }^{\circ} \mathrm{C}$ with the average temperature of $14.5^{\circ} \mathrm{C}$. The climate in this area is monsoonal with high rainfall during the summer in July (total rainfall $215.1 \mathrm{~mm}$ ) and August (total rainfall $225.6 \mathrm{~mm}$ ), which are almost $47 \%$ of the annual precipitation. Field survey was conducted prior to flooding (pre-flooding; 4-5 June 2019) and after flooding (post-flooding 1; 26-27 August 2019 and post- flooding 2; 7 October 2019). In pre-flooding, total monthly rainfall was only $25.5 \mathrm{~mm}$, and there were almost no variations in water level, whereas there were dynamic variations in water level before post-flooding 1 and postflooding 2 (Additional file 1: Figure S2).

In the study site, six replicate permanent line transects were established perpendicular to the river channel, and five quadrats of $2.25 \mathrm{~m}^{2}(1.5 \mathrm{~m} \times 1.5 \mathrm{~m})$ were established within each line transect (total 30 quadrats). For each quadrat, distance from the water front and elevation above the water level were measured. The elevation of quadrats adjacent to the river channel was set to $0 \mathrm{~cm}$, and differences of elevation were measured using a clinometer. The distance and the relative elevation of a total of 30 quadrats varied from 0 to $10.5 \mathrm{~m}$ and 0 to $116 \mathrm{~cm}$, respectively. Quadrats were classified into three different groups (hereafter, these are referred to as low, middle, and high elevation) according to their dominant vegetation cover. Low elevation $(n=6)$, located adjacent to the river channel $(0 \mathrm{~cm}$ to the river), was dominated by obligate wetland plants, such as Zizania latifolia. Middle elevation $(n=10)$, located $<26 \mathrm{~cm}$ above the water level and $<6.5 \mathrm{~m}$ from the water front, was mostly dominated by Polygonum thunbergii. High elevation $(n=14)$, where distinctive plants dominated according to season, located $28-116 \mathrm{~cm}$ above the water level and $5.5-10.5 \mathrm{~m}$ from the water front.

Average height, density, and coverage of every species emerged in $1.5 \mathrm{~m} \times 1.5 \mathrm{~m}$ quadrats were surveyed. Some immature or juvenile plants were identified only to the family level. According to the literature by Choung et al. (2012), plant species were classified into five categories based on the frequency of each species in its habitats as follows: obligate upland plant (OBU), facultative upland plant (FACU), facultative plant (FAC), facultative wetland plant (FACW), and obligate wetland plant (OBW). The obligate and facultative wetland plants were classified into hygrophyte and emergent macrophytes based on the degree of wetness of their habitats (Choung et al. 2012). As soils were not homogeneous within a quadrat, three soil samples at a depth of $0-20 \mathrm{~cm}$ from the soil top layer were randomly collected from each quadrat, obtaining a total of 90 soil samples for each survey period.

\section{Soil physicochemical properties}

Prior to analysis, soil samples were sieved through a 2$\mathrm{mm}$ mesh (standard sieve \#10) to remove any plant material or gravel, mixed thoroughly, and stored at $4{ }^{\circ} \mathrm{C}$. Each $100 \mathrm{~g}$ of subsample was dried at $80{ }^{\circ} \mathrm{C}$ for soil texture analysis. The soil moisture content was measured based on the weight loss of soil dried at $105{ }^{\circ} \mathrm{C}$ in an oven for over $48 \mathrm{~h}$, and the organic matter content was determined by loss of ignition (LOI) at $550{ }^{\circ} \mathrm{C}$ for $4 \mathrm{~h}$ (Boyle 2004). The soil $\mathrm{pH}$ and electric conductivity (EC) 
were measured in a 1:5 (w/v) soil/deionized water suspension solution using a $\mathrm{pH}$ meter and a conductivity meter, respectively. Soil texture was determined using the hydrometer method and the soil texture triangle of USDA (Sheldrick and Wang 2007). $\mathrm{NO}_{3}-\mathrm{N}$ and $\mathrm{NH}_{4}-\mathrm{N}$ were extracted with $2 \mathrm{M} \mathrm{KCl}$ solution, and concentrations were measured using hydrazine method (Kamphake et al. 1967) and indo-phenol method (Murphy and Riley 1962), respectively. $\mathrm{PO}_{4}-\mathrm{P}$ concentration was determined using ascorbic acid reduction method (Solorzano 1969) after extraction with Bray No. 1 solution (Bray and Kurtz 1945). Exchangeable cation concentrations $\left(\mathrm{K}^{+}, \mathrm{Na}^{+}, \mathrm{Ca}^{2+}\right.$, and $\left.\mathrm{Mg}^{2+}\right)$ were measured using an atomic absorption spectrometer (model AA240FS; Varian, USA) after extraction with $1 \mathrm{~N}$ ammonium acehtate solution (Allen et al. 1974). All results were expressed on an oven dry soil basis.

\section{Data analysis}

The response of major species along a gradient of elevation was determined using a Huisman-Olff-Fresco (HOF) model (Huisman et al. 1993). HOF model comprises a hierarchical set of predetermined models with increasing complexity, and the best model is chosen by comparing a statistical information criterion including the goodness-offit and model complexity (Burnham and Anderson 2002). Coverage data were square root transformed, and total 7 , 8 , and 6 species were selected as major species based on their frequencies (more than 3 quadrats) and total coverage (above 100\%) for pre-flooding, post-flooding 1, and post-flooding 2, respectively. Community classification was conducted using TWINSPAN (Two-way indicator species analysis). The cut levels were selected as $2,5,10$, and 20. Huisman-Olff-Fresco model and TWINSPAN were performed using $\mathrm{R}$ version 3.6.1 with package eHOF (Jansen and Oksanen 2013) and twinspanR, respectively ( $\mathrm{R}$ Core Team 2018). The relationships between vegetation and environmental factors were examined using the CANOCO for Windows 4.5 statistical package (Ter Braak and Smilauer 2002). Since preliminary analysis using detrended correspondence analysis (DCA) suggested a linear response by the species (the length of first axes $=0.65$, 0.53 , and 0.47 for pre-flooding, post-flooding 1 , and postflooding 2, respectively), a linear model with redundancy analysis (RDA) was carried out in order to analyze the relationship between vegetation and environmental factors. For this analysis, rare species, which appeared at only one quadrat for each period, were excluded to reduce their influence on the ordination. The Monte Carlo permutation test with 999 permutations was applied to identify the statistical significance of canonical axes and environmental factors to explain the variance of vegetation. Significance level was 0.05 for all performed statistical tests.

\section{Results}

\section{Species composition and distribution patterns}

In this study, vegetation structure was affected by flooding, resulting in temporal and spatial variations. There was an obvious temporal variation in species composition (Fig. 1, Additional file 1: Table S1). Zizania latifolia, Polygonum thunbergii, and Phragmites australis were dominant throughout the field survey periods. Prior to flooding, Scirpus radicans, Artemisia vulgaris, Galium spurium, and Miscanthus sacchariflorus were dominant, while $M$. sacchariflorus was widely distributed until post-flooding 1 . In post-flooding 1 , Actinostemma lobatum and Sicyos angulatus were dominant. Bidens frondosa and Humulus scandens began to grow late and dominated both in post-flooding 1 and 2 . In postflooding 2, Artemisia princeps was dominant.

There were significant spatial variations in species composition and distribution patterns (Fig. 2, Additional file 1: Table S1). Spatial difference showed a clear relationship with the elevation above the water level. Prior to flooding, Z. latifolia, an obligate wetland plant, was widely distributed at low-lying areas, especially dominant at the elevation of $0 \mathrm{~cm}$. Scirpus radicans was widely distributed below the elevation of $20 \mathrm{~cm}$. Polygonum thunbergii and A. vulgaris were dominant within a range of elevations of $8-26 \mathrm{~cm}$ and $26-45 \mathrm{~cm}$, respectively, which are periodically flooded. Phragmites australis, which is an obligate wetland plant, was widely distributed at elevations of $57-110 \mathrm{~cm}$. Miscanthus sacchariflorus was observed above the elevation of $80 \mathrm{~cm}$.

After flooding, species composition and distribution patterns have changed. Zizania latifolia and B. frondosa were constantly dominant at low elevation both in postflooding 1 and 2. Polygonum thunbergii was dominant at middle elevation with most other species decreasing. Phragmites australis was widely distributed at high elevation. Invasive or pioneer plants, including $A$. princeps, $H$. scandens, and $S$. angulatus, were observed above the elevation of $28 \mathrm{~cm}$. In post-flooding 2, $P$. thunbergii was still distributed over a wide range of periodically flooded areas. Obligate upland plants including $A$. princeps and $H$. scandens were widely distributed above the elevation of $19 \mathrm{~cm}$, and $P$. australis was dominant above the elevation of $28 \mathrm{~cm}$.

\section{Relationship between vegetation and environmental factors}

TWINSPAN classified 30 quadrats of pre-flooding and post-flooding 1 and 2 into 6 (labeled A1-A6), 5 (labeled B1-B5), and 3 groups (labeled $\mathrm{C} 1-\mathrm{C} 3$ ), respectively (Fig. 3). A1 includes 6 quadrats dominated by $Z$. latifolia and was located at low elevation. Seven quadrats of A2 were dominated by P. thunbergii and were located at middle elevation. Artemisia vulgaris 


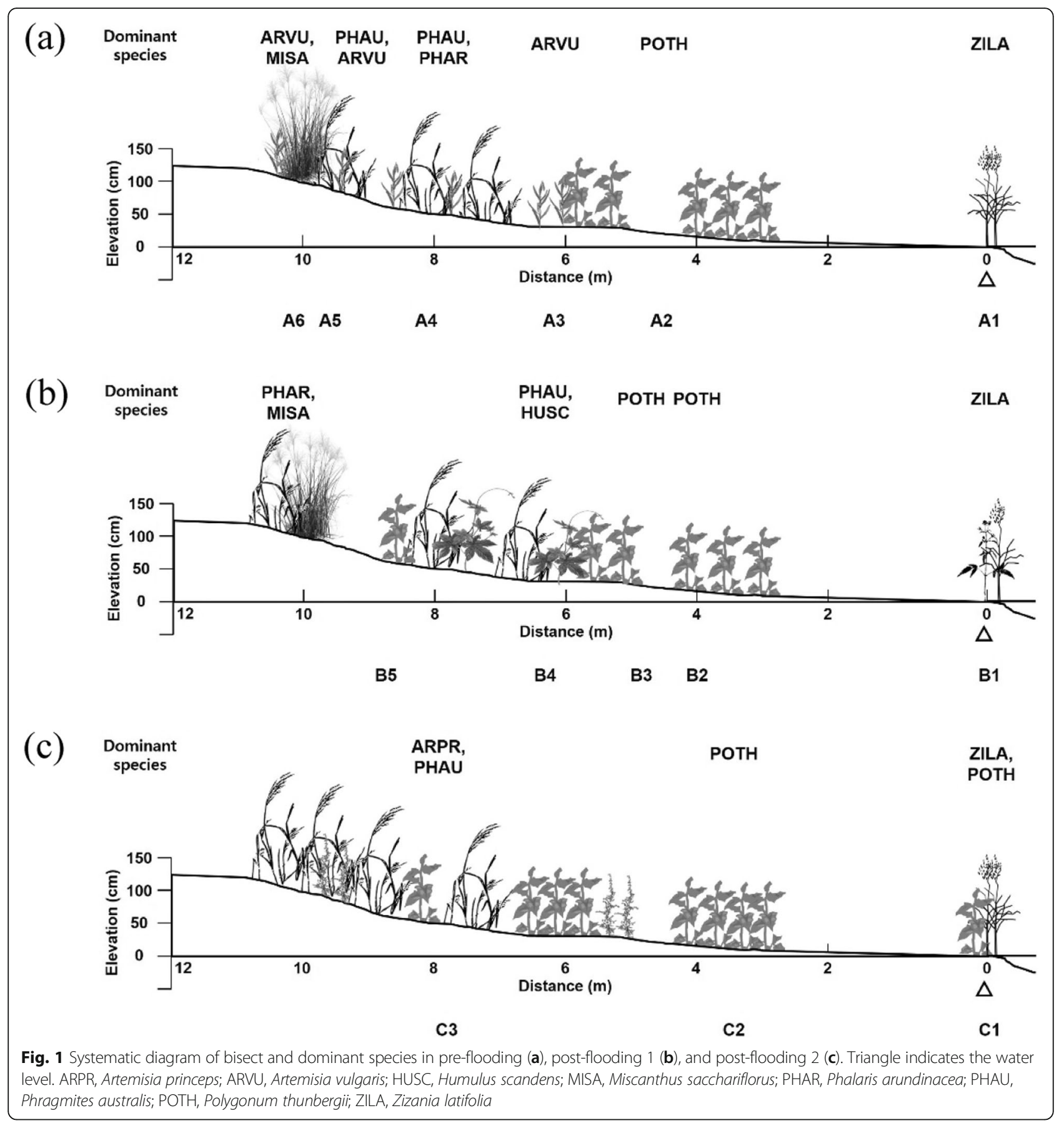

was a common species at A3, A4, A5, and A6, which were located at high elevation. A3 comprises 5 quadrats dominated by $A$. vulgaris. A4 includes 2 quadrats, where $P$. australis, $P$. arundinacea, and $A$. vulgaris were common species. Eight quadrats of A5 were closely related to $A$. vulgaris, P. australis, and G. spurium. A6 includes 2 quadrats, where A. vulgaris and $M$. sacchariflorus were common species.

After flooding, classification of vegetation changed. B1 includes 6 quadrats which were located at low elevation, where Z. latifolia and B. frondosa were common species. B2 and B3 comprise 1 and 10 quadrats, respectively, dominated by $P$. thunbergii, and most of them were located at middle elevation. B4 includes 9 quadrats dominated by $P$. australis and $H$. scandens. Four quadrats of B5 were closely related to $P$. australis and $M$. sacchariflorus. The most common species in $\mathrm{C} 1$, including 8 quadrats, were Zizania latifolia, B. frondosa, and $P$. thunbergii. Eleven quadrats of $\mathrm{C} 2$ were dominated by $P$. thunbergii, where $H$. scandens was a common species. 
(a)

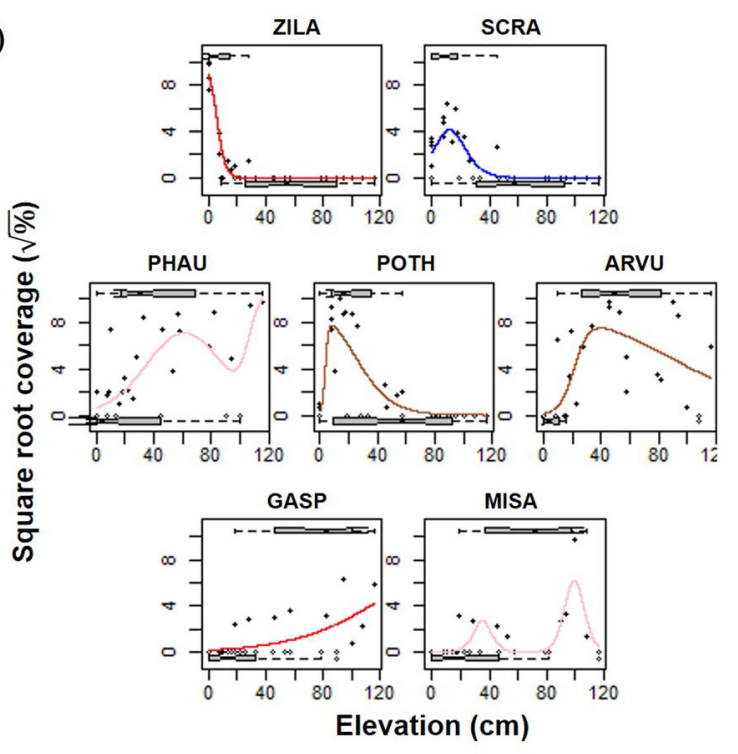

(b)

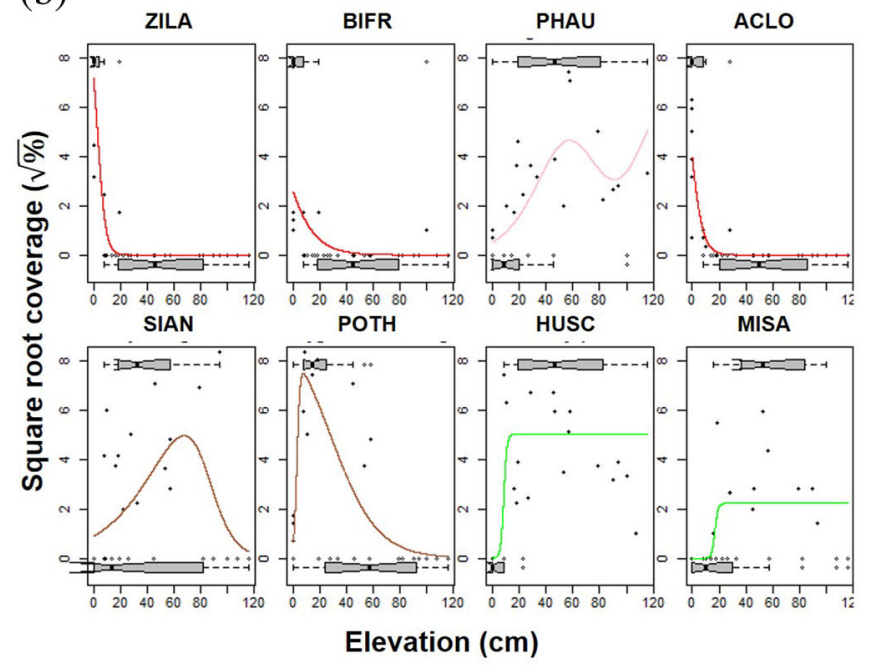

(c)

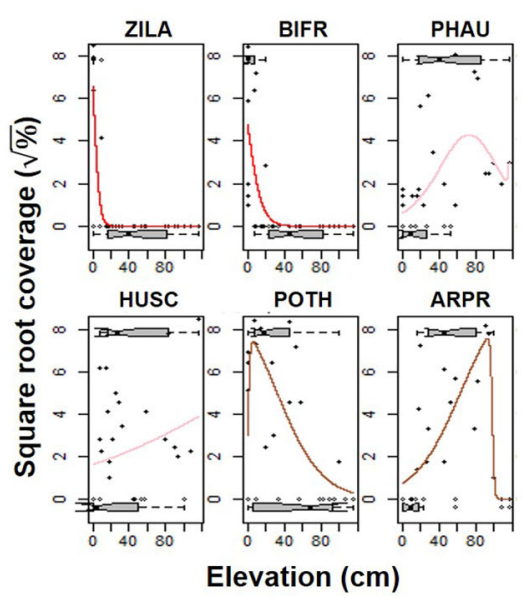

Fig. 2 (See legend on next page.) 
(See figure on previous page.)

Fig. 2 Huisman-Olff-Fresco (HOF) analysis of species coverage data (square root transformed) of the most abundant species with respect to elevation in pre-flooding (a), post-flooding 1 (b), and post-flooding 2 (c). ACLO, Actinostemma lobatum; ARPR, Artemisia princeps; ARVU, Artemisia vulgaris; BIFR, Bidens frondosa; GASP, Galium spurium; HUSC, Humulus scandens; MISA, Miscanthus sacchariflorus; PHAU, Phragmites australis; POTH, Polygonum thunbergii; SIAN, Sicyos angulatus; ZILA, Zizania latifolia

C3 includes 11 quadrats, where $P$. australis and A. princeps were common species.

The redundancy analysis (RDA) ordination displayed scores for all of the quadrats with the arrows indicating the relative directions and strengths of the gradients of environmental factors (Fig. 4). When plotted on the RDA ordination axes, the quadrats tended to be separated into the vegetation community resulted from TWINSPAN. Furthermore, RDA showed clear separation of the quadrats according to the elevation (low, middle, and high). The first two axes explained 55.3\%, $43.7 \%$, and $42.6 \%$ of the variance in pre-flooding, postflooding 1 , and post-flooding 2 , respectively. Distance and elevation were the most principal factors determining vegetation for all periods. Prior to flooding, moisture content was the most primary factors explaining $27 \%$ of the variation (Monte Carlo permutation test with 999 permutations, $F=10.5, p<0.001$ ), followed by distance and elevation explaining $16 \%(F=7.47, p<0.001)$ and $8 \%(F=4.19, p<0.01)$, respectively (Fig. 4a). Furthermore, organic matter content, sand content, and $\mathrm{Na}^{+}$ concentration could explain $7 \%(F=3.95, p<0.01), 4 \%$ $(F=2.84, p<0.05)$, and $4 \%(F=2.37, p<0.05)$ of the variation, respectively. After flooding, main factors responsible for the variation of vegetation changed. The RDA of post-flooding 1 indicated that distance and elevation were still the most primary factors explaining $20 \%(F=6.79, p<0.001)$ and $17 \%(F=7.43, p<0.001)$ of the variation, respectively (Fig. $4 \mathrm{~b}$ ). $\mathrm{Ca}^{2+}$ and $\mathrm{PO}_{4}-\mathrm{P}$ concentrations could explain $8 \%(F=4.06, p<0.01)$ and $7 \%(F=3.32, p<0.01)$, respectively. The RDA of postflooding 2 revealed that organic matter content was the most principal factor explaining $25 \%(F=9.51, p<0.001)$ of the variation, followed by distance and elevation explaining $15 \%(F=6.38, p<0.001)$ and $5 \%(F=2.38, p<0.05)$, respectively (Fig. 4c).

\section{Discussion}

In the riparian zone, topographic factors including elevation above the water level and distance from the water front were major factors affecting hydrological characteristics. As elevation and distance increase away from the water front, frequency, duration, and magnitude of flooding decrease. Such hydrological regime is a major determinant of species composition and distribution patterns in the riparian zone (Casanova and Brock 2000). In other words, variations in elevation and distance create spatial differences in hydrological regime, and the hydrological gradients control the establishment and development of vegetation in the riparian zone (Ferreira and Stohlgren 1999, Casanova and Brock 2000).

Elevation from the water level and distance from the water front were the most primary factors determining species composition and distribution patterns. The riparian vegetation exhibited a zonation pattern perpendicular to the river channel, resulting in spatial variation of vegetation along the elevation. Zonation of vegetation is determined by hydrological regime and inherent characteristics of species, especially species differences in tolerance to floods or droughts (Shafroth et al. 2002, Auble et al. 2005). Low elevation sites, which tend to be permanently or periodically flooded, were dominated by a single species tolerant to floods, such as Z. latifolia and $P$. thunbergii. The growth of $Z$. latifolia responded positively to high water level (Byun et al. 2017), and it could survive in deep water up to $60 \mathrm{~cm}$ above the soil surface and grow well in shallow water, up to $30 \mathrm{~cm}$ (Yamasaki and Tange 1981). Polygonum thunbergii could survive as creeping stems, which are parallel with the water flow and firmly fixed to the ground, making new shoots rapidly resulting in recovery of their biomass after flooding (Kim et al. 2012). Also, simple flooding during early or late vegetative growth did not affect the formation of amphicarpic seeds as well as vegetative parts (Choo et al. 2014). Miscanthus sacchariflorus, which is known to be a resister against flooding by standing rather than being fallen, was widely observed at high elevation both in preflooding and post-flooding 1 (Cho and Cho 2005). On the contrary, obligate upland plants intolerant to flooding, such as A. princeps, G. max subsp. soja, and H. scandens, were widely distributed at high elevation. Such obligate upland plants are intolerant of flooding and die following long periods of flooding (Capon 2003). Invasive species, including $H$. scandens and $S$. angulatus, were also observed at higher elevation. At lower elevation, constant flooding disturbance might have suppressed invasive species, while at middle species, in which species composition was complex and various, native species utilize limited resources more completely, thus preventing invasion (McNaughton 1983).

Species composition and distribution patterns were homogeneous at low elevation, and dominant species did not change significantly over period. In contrast, dynamic variations of vegetation were observed both temporally and spatially at higher elevations. These findings are consistent with previous studies showing the 


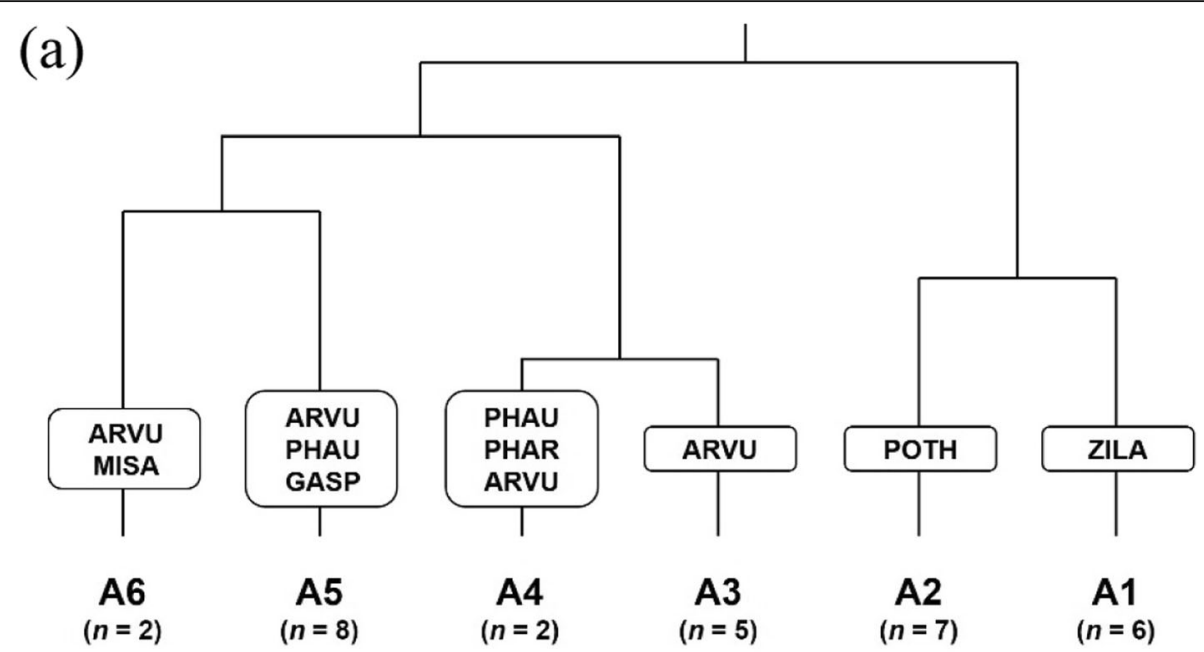

(b)

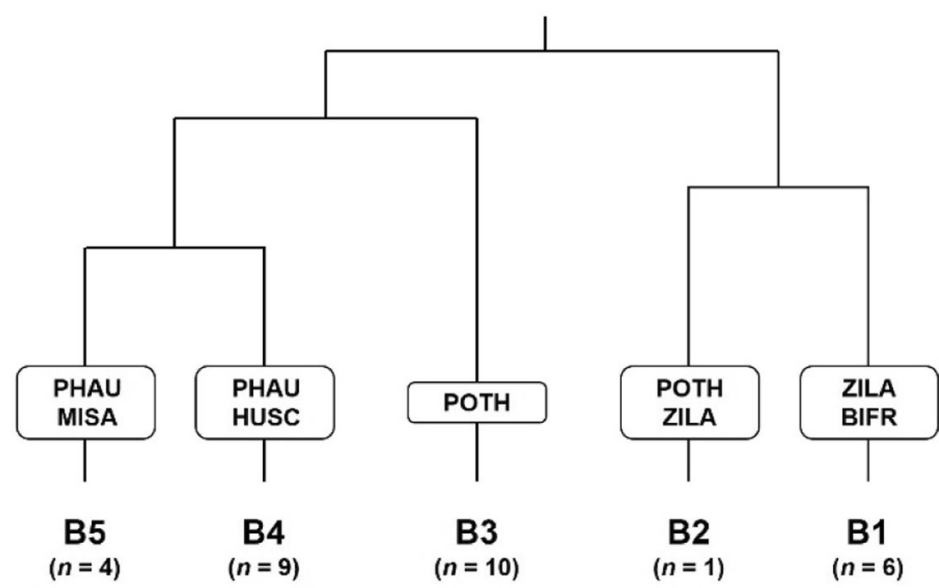

(c)

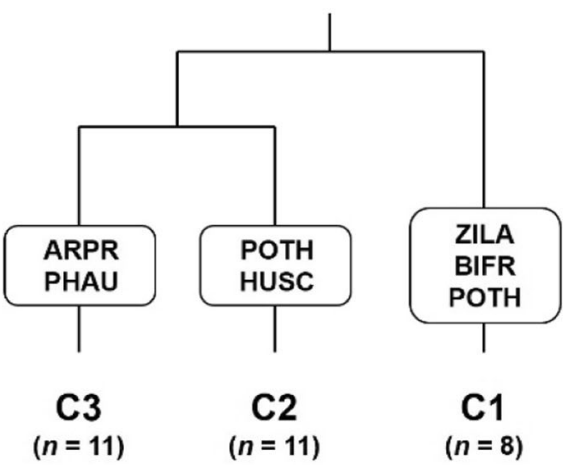

Fig. 3 TWINSPAN dendrogram of pre-flooding (a), post-flooding 1 (b), and post-flooding 2 (c) with indicator species for each group. The number of vegetation quadrats in each group is indicated in parentheses. ARPR, Artemisia princeps; ARVU, Artemisia vulgaris; BIFR, Bidens frondosa; GASP, Galium spurium; HUSC, Humulus scandens; MISA, Miscanthus sacchariflorus; PHAR, Phalaris arundinacea; PHAU, Phragmites australis; POTH, Polygonum thunbergii; TWINSPAN, Two-way indicator species analysis; ZILA, Zizania latifolia

homogeneity of vegetation at low elevation, and the wide range of variations found at higher elevation (Nakamura et al. 1997, Capon 2005, Jager et al. 2012). Since only a few species tolerant to flooding are able to dominate low-lying area, which experience high stress of flooding disturbance, there is less competition from other species resulting in the homogeneity of vegetation. High elevation with low flooding disturbance, however, may enable various species to establish. Therefore, biotic factors, such as competition, are likely to be more important in determining species composition at high elevation (Blom et al. 1990). 
(a)

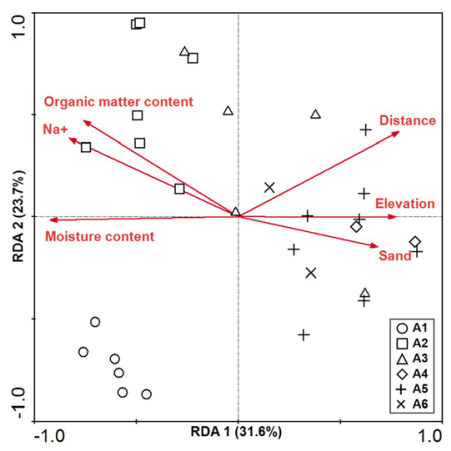

(b)

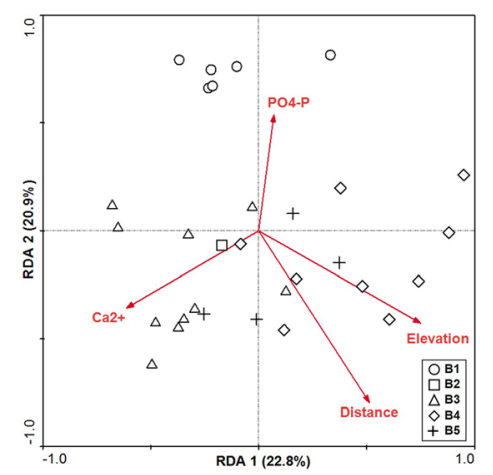

(c)

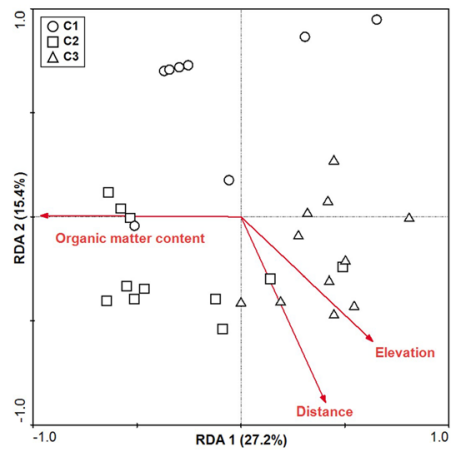

Fig. 4 Redundancy analysis (RDA) ordination of vegetation quadrats $(n=30)$ and environmental factors (arrows) for pre-flooding (a), post-flooding 1 (b), and post-flooding 2 (c). For environmental factors, only significant environmental factors explaining the variance of vegetation based on Monte Carlo permutation test were shown. For a guide to the abbreviations used for each group such as A1-A6, B1-B5, and C1-C3, see Fig. 3

In addition to the effects of hydrological gradient, soil physicochemical properties could affect riparian vegetation. Topographic factors including the elevation above the water level and the distance from the water front create heterogeneity of soil physicochemical properties which has an effect on the vegetation structure (Vivian-Smith 1997). In this study, based on RDA, moisture content, organic matter content, $\mathrm{pH}$, $\mathrm{EC}$, and nutrient availability were found to govern species composition and distribution patterns, and flooding altered the principal factors governing vegetation structure (Fig. 4). Moisture content was the primary factor driving vegetation patterns in a riparian zone as shown in other studies (Xu et al. 2015). Variations in soil moisture content are due to elevation above the water level and distance from the water front. Many previous studies have reported that hydrological gradient including soil moisture content and water depth along the elevation was the primary factor determining vegetation (van Coller et al. 2000, Hupp and Rinaldi 2007, Yabe and Onimaru 2009). Several other soil physicochemical properties other than soil moisture content, such as organic matter content (Eskelinen et al. 2009), pH (Asada 2002), EC (Ladenburger et al. 2006), and nutrient availability (Wassen et al. 2003) also affected species composition and distribution patterns of vegetation, which is consistent with previous studies. In other words, variations in vegetation are formed by the combined effects of hydrological gradient and variations in soil physicochemical properties.

These results suggested that a better understanding of riparian vegetation requires a synthesis of all of the environmental factors including hydrological regime and soil physicochemical properties, inherent characteristics of species, and interspecific competition.
Understanding of temporal and spatial variations in riparian vegetation would ultimately contribute to improved understanding of dynamics of riparian zones. This study may provide useful insights into ecological restoration and conservation of the vegetation within the riparian zones.

\section{Conclusions}

In this study, we conducted field survey in a riparian zone of Namhan River in South Korea both before and after flooding in order to understand temporal and spatial variations of riparian vegetation. Flooding induced variations of hydrological regime leading to variations of vegetation. There were significant temporal and spatial variations in species composition, and distribution patterns of vegetation were different along a gradient of elevation from the water level. Low elevation sites, which tend to be permanently or periodically flooded, were dominated by a single species tolerant to floods, such as $Z$. latifolia and $P$. thunbergii. On the contrary, obligate upland plants intolerant to flooding, such as A. princeps, G. $\max$ subsp. soja, and $H$. scandens, were widely distributed at high elevation. Invasive species including $H$. scandens and $S$. angulatus were also observed at higher elevation. Species composition and distribution patterns were homogeneous at low elevation, whereas dynamic variations of vegetation were observed both temporally and spatially at higher elevations. In addition to topography including elevation and distance, soil physicochemical properties such as moisture content, organic matter content, $\mathrm{pH}, \mathrm{EC}$, and nutrient availability were also found to determine species composition and distribution patterns. These results indicated that vegetation structure in the riparian zones is formed by the combined effects of 
all of the environmental factors including hydrological regime and soil physicochemical properties, inherent characteristics of species, and interspecific competition. Understanding of temporal and spatial variations in riparian vegetation may provide useful insights into ecological restoration and conservation of the vegetation within the riparian zones.

\section{Supplementary information}

Supplementary information accompanies this paper at https://doi.org/10 1186/s41610-020-00152-z.

Additional file 1: Table S1. List of species observed at each elevation (low, middle, and high) in pre-flooding, post-flooding 1, and postflooding 2 in the studied riparian zone. Figure $\mathbf{S 1}$. The map of study site and schematic diagram of field survey. Figure S2. Variations of water level from January to October 2019 at the study site.

\section{Abbreviations}

ACLO: Actinostemma lobatum; ARPR: Artemisia princeps; ARVU: Artemisia vulgaris; BIFR: Bidens frondosa; DCA: Detrended correspondence analysis; EC: Electric conductivity; EMER: Emergent macrophytes; FAC: Facultative plant; FACU: Facultative upland plant; FACW: Facultative wetland plant; GASP: Galium spurium; H: High elevation; HOF: Huisman-Olff-Fresco; HUSC: Humulus scandens; HYG: Hygrophyte; L: Low elevation; M: Middle elevation; MISA: Miscanthus sacchariflorus; OBU: Obligate upland plant; OBW: Obligate wetland plant; PHAR: Phalaris arundinacea; PHAU: Phragmites australis; POTH: Polygonum thunbergii; RDA: Redundancy analysis; SIAN: Sicyos angulatus; TWINSPAN: Two-way indicator species analysis; ZILA: Zizania latifolia

\section{Acknowledgements}

We would like to thank Ho Choi, Bo Eun Nam, Ga-yeon Son, and Hyun Jun Park in Seoul National University for advising and supporting in the field survey. This research was supported by Basic Science Research Program (NRF2015R1D1A1A01057373) through the National Research Foundation of Korea funded by the Ministry of Education and by the National Research Foundation of Korea grant (NRF-2018R1A2B2002267) funded by the Korea government of Ministry of Science and ICT.

\section{Authors' contributions}

HP performed the field survey, analyzed experimental data, and wrote the manuscript draft. JGK conceived the research idea and edited the manuscript. The authors read and approved the final manuscript.

\section{Availability of data and materials}

The datasets generated during and/or analyzed during the current study are available from the corresponding author on reasonable request.

\section{Competing interests}

The authors declare that they have no competing interests.

\section{Ethics approval and consent to participate}

Not applicable.

\section{Consent for publication}

Not applicable.

Received: 22 January 2020 Accepted: 5 March 2020

Published online: 03 April 2020

\section{References}

Allen SE, Grimshaw HM, Parkinson JA, Quarmby C. Chemical analysis of ecological materials. Oxford: Blackwell Scientific Publication; 1974.

Asada T. Vegetation gradients in relation to temporal fluctuation of environmental factors in Bekanbeushi peatland, Hokkaido. Japan. Ecol Res. 2002;17:505-18.
Auble GT, Scott ML, Friedman JM. Use of individualistic streamflow-vegetation relations along the Fremont River, Utah, USA to assess impacts of flow alteration on wetland and riparian areas. Wetlands. 2005;25:143-54.

Baldwin DS, Mitchell AM. The effects of drying and re-flooding on the sediment and soil nutrient dynamics of lowland river-floodplain systems: a synthesis. Regul River. 2000;16:457-67.

Blom CWPM, Voesenek LACJ. Flooding: the survival strategies of plants. Trends Ecol Evol. 1996;11:290-5.

Blom CWPM, Voesenek LACJ, Banga M, Engelaar WMHG, Rijnders JHGM, Van De Steeg HM, Visser EJW. Physiological ecology of riverside species: adaptive responses of plants to submergence. Ann Bot. 1990;38:29-47.

Boyle J. A comparison of two methods for estimating the organic matter content of sediments. J Paleolimnol. 2004;31:125-7.

Bray RH, Kurtz LT. Determination of total, organic and extracted forms of phosphorus in soil. Soil Sci. 1945;59:39-46.

Burnham KP, Anderson DR. Model selection and multimodel inference: a practical information-theoretic approach. Berlin: Springer; 2002.

Byun C, Nam JM, Kim JG. Effects of flooding regime on wetland plant growth and species dominance in a mesocosm experiment. Plant Ecol. 2017;218: 517-27.

Capon SJ. Plant community responses to wetting and drying in a large arid floodplain. River Res Appl. 2003;19:509-20.

Capon SJ. Flood variability and spatial variation in plant community composition and structure on a large arid floodplain. J Arid Environ. 2005;60:283-302.

Casanova MT, Brock MA. How do depth, duration and frequency of flooding influence the establishment of wetland plant communities? Plant Biol. 2000; 147:237-50.

Chen X, Li X, Xie Y, Li F, Hou Z, Zeng J. Combined influence of hydrological gradient and edaphic factors on the distribution of macrophyte communities in Dongting Lake wetlands, China. Wetl Ecol Manag. 2015;23:481-90.

$\mathrm{Cho} \mathrm{HJ}$, Cho KH. Responses of riparian vegetation to flooding disturbance in a sand stream. J Civil Eng. 2005:9:49-53.

Choo Y-H, Kim H-T, Nam JM, Kim JG. Flooding effects on seed production of the amphicarpic plant Persicaria thunberbii. Aquat Bot. 2014;119:15-9.

Choung YS, Lee WJ, Jo KH, Min BM, Hyun JO, Lee GS. Categorizing vascular plant species occurring in wetland ecosystems of the Korean peninsula. Chuncheon: Center for aquatic ecosystem restoration; 2012.

Darbey SE. Effect of riparian vegetation on flow resistance and flood potential. J Hydraul Eng. 1999;125:443-54

Dosskey MG, Vidon P, Gurwick NP, Allan CJ, Duval TP, Lowrance R. The role of riparian vegetation in protecting and improving chemical water quality in streams. J Am Water Resour As. 2010;46:261-77.

Eskelinen A, Stark S, Männistö M. Links between plant community composition, soil organic matter quality and microbial communities in contrasting tundra habitats. Oecologia. 2009;161:113-23.

Fail JL, Haines BL, Todd RL. Riparian forest communities and their role in nutrient conservation in an agricultural watershed. Am J Alternative Agr. 1987;2:114-21.

Ferreira LV, Stohlgren TJ. Effects of river level fluctuation on plant species richness, diversity, and distribution in a floodplain forest in Central Amazonia. Oecologia. 1999;120:582-7.

Hefting M, Clément JC, Dowrick D, Cosandey AC, Bernal S, Cimpian C, Tatur A, Burt TP, Pinay G. Water table elevation controls on soil nitrogen cycling in riparian wetlands along a European climatic gradient. Biogeochemistry. 2004; 67:113-34

Huisman J, Olff H, Fresco LFM. A hierarchical set of models for species response analysis. J Veg Sci. 1993;4:37-46.

Hupp CR, Rinaldi M. Riparian vegetation patterns in relation to fluvial landforms and channel evolution along selected rivers of Tuscany (Central Italy). Ann Assoc Am Geogr. 2007:97:12-30.

Jager NRD, Thomsen M, Yin Y. Threshold effects of flood duration on the vegetation and soils of the upper Mississippi River floodplain. USA. Forest Ecol Manag. 2012;270:135-46.

Jansen F, Oksanen J. How to model species responses along ecological gradients - Huisman-Olff-Fresco models revisited. J Veg Sci. 2013;24:1108-17.

Jolley RL, Lockaby BG, Cavalcanti GG. Changes in riparian forest composition along a sedimentation rate gradient. Plant Ecol. 2010;210:317-30.

Kamphake LJ, Hannah SA, Cohen JM. Automated analysis for nitrate by hydrazine reduction. Water Res. 1967;1:205-16.

Kim DH, Choi H, Kim JG. Occupational strategy of Persicaria thunbergii in riparian area: rapid recovery after harsh flooding disturbance. J Plant Biol. 2012;55: 226-32. 
Knight AW, Bottorff RL. The importance of riparian vegetation to stream ecosystems. In: Warner RE, Hendrix KM, editors. California riparian systems, ecology, conservation, and productive management. California: Univ. of California Press; 1984

Ladenburger CG, Hild AL, Kazmer DJ, Munn LC. Soil salinity patterns in Tamarix invasions in the Bighorn Basin, Wyoming. USA. J Arid Environ. 2006;65:111-28.

McNaughton SJ. Compensatory plant growth as a response to herbivory. Oikos. 1983;40:329-36

Murphy J, Riley JP. A modified single solution method for the determination of phosphate in natural waters. Anal Chim Acta. 1962;27:31-6.

Naiman RJ, Bechtold JS, Drake DC, Latterell JJ, O'Keefe TC, Balian EV. Origins, patterns, and importance of heterogeneity in riparian systems. In:Lovett GM, Turner MG, Weather KC, editors. Ecosystem Function in Heterogeneous Landscapes. New York: Springer; 2005.

Nakamura F, Yajima T, Kikuchi S. Structure and composition of riparian forests with special reference to geomorphic site conditions along the Tokachi River, northern Japan. Plant Ecol. 1997;133:209-19.

Nilsson C, Grelsson G, Johansson M, Sperens U. Patterns of plant species richness along riverbanks. Ecology. 1989;70:77-84.

Parolin P. Submergence tolerance vs. escape from submergence: two strategies of seedling establishment in Amazonian floodplains. Environ Exp Bot. 2002; 48:177-86.

Pennington DN, Hansel J, Blair RB. The conservation value of urban riparian areas for landbirds during spring migration: land cover, scale, and vegetation effects. Biol Conserv. 2008;141:1235-48.

Polvi LE, Wohl EE, Merritt DM. Geomorphic and process domain controls on riparian zones in the Colorado Front Range. Geomorphology. 2011;125: 504-16.

R Core Team. R: A language and environment for statistical computing. Vienna, Austria: R foundation for statistical computing; 2018.

Shafroth PB, Stomberg JC, Patten DT. Riparian vegetation response to altered disturbance and stress regimes. Ecol Appl. 2002;12:107-23.

Sheldrick BH, Wang C. Particle Size Distribution. In: Carter MR, Gregorich EG, editors. Soil sampling and methods of analysis. Florida: Lewis Publishers; 2007.

Solorzano L. Determination of ammonia in natural waters by the phenolhypochlorite method. Limnol Oceanogr. 1969;14:799-801.

Steiger J, Tabacchi E, Dufour S, Corenblit D, Peiry J-L. Hydrogeomorphic processes affecting riparian habitat within alluvial channel-floodplain river systems: a review for the temperate zone. River Res Appl. 2005;21:719-37.

Tabacchi E, Lambs L, Guilloy H, Planty-Tabacchi A-M, Muller E, Décamps H. Impacts of riparian vegetation on hydrologic processes. Hydrol Process. 2000; 14:2959-76.

Ter Braak CJF, Smilauer P. CANOCO reference manual and CanoDraw for Windows user's guide: software for canonical community ordination (version 4.5). New York: Microcomputer Power; 2002.

van Coller AL, Rogers KH, Heritage GL. Riparian vegetation-environment relationships: complimentarity of gradients versus patch hierarchy approaches. J Veg Sci. 2000;11:337-50.

Vandersande MW, Glenn EP, Walworth JL. Tolerance of five riparian plants from the lower Colorado River to salinity drought and inundation. J Arid Environ. 2001;49:147-59.

Vivian-Smith G. Microtopographic heterogeneity and floristic diversity in experimental wetland communities. J Ecol. 1997;85:71-82.

Wassen MJ, Peeters WHM, Venterink HO. Patterns in vegetation, hydrology, and nutrient availability in an undisturbed river floodplain in Poland. Plant Ecol. 2003;165:27-43.

Xiaoling L, Ning L, Jin Y, Fuzhou Y, Faju C, Fangqing C. Morphological and photosynthetic responses of riparian plant Distylium chinense seedlings to simulated autumn and winter flooding in Three Gorges Reservoir of the Yangtze River. China. Acta Ecol Sin. 2011;31:31-9.

Xu X, Zhang Q, Tan Z, Li Y, Wang X. Effects of water-table depth and soil moisture on plant biomass, diversity, and distribution at a seasonally flooded wetland of Poyang Lake. China. Chinese Geogr Sci. 2015;25:739-56.

Yabe K, Onimaru K. Key variables controlling the vegetation of a cool-temperate mire in northern Japan. J Veg Sci. 2009;8:29-36.

Yamasaki S, Tange I. Growth response of Zizania latifolia, Phragmites australis and Miscanthus sacchariflorus to varying inundation. Aquat Bot. 1981;10:229-39.

\section{Publisher's Note}

Springer Nature remains neutral with regard to jurisdictional claims in published maps and institutional affiliations.

\section{Ready to submit your research? Choose BMC and benefit from:}

- fast, convenient online submission

- thorough peer review by experienced researchers in your field

- rapid publication on acceptance

- support for research data, including large and complex data types

- gold Open Access which fosters wider collaboration and increased citations

- maximum visibility for your research: over $100 \mathrm{M}$ website views per year

At BMC, research is always in progress.

Learn more biomedcentral.com/submissions 